\title{
Phytotherapy for diabetes mellitus; A review of Middle Eastern and North African folk medicinal plants
}

\author{
Sara S. Abou Zekry ${ }^{1}$, Marwa T. Badawy $^{1}$, Nada M. Ezzelarab ${ }^{2}{ }^{\mathbb{D}}$, Ahmed Abdellatif $^{1,2^{*}}$ \\ ${ }^{1}$ Biotechnology Program, School of Sciences and Engineering, the American University in Cairo, 11835, Egypt \\ ${ }^{2}$ Department of Biology, School of Sciences and Engineering, the American University in Cairo, 11835, Egypt
}

\section{A R T I C L E I N F O \\ Article Type: \\ Review \\ Article History: \\ Received: 18 January 2020 \\ Accepted: 6 May 2020 \\ Keywords: \\ Diabetes mellitus \\ Anti-diabetic drugs \\ Anti-diabetic plants \\ Phytomedicine \\ Herbal medicine \\ Folk medicine}

\begin{abstract}
A B S T R A C T
Diabetes mellitus (DM) is considered as one of the most common metabolic disorders affecting huge number of people worldwide. Despite the availability of large numbers of drugs in the market to treat the disease, there is still a need for new sources to deal with the problem and avoid side effects. In the pursuit of discovering safer and more effective antidiabetic drugs, herbal and folk medicine drugs from regions all over the world have captured researchers' interest. Middle Eastern and North African medicinal plants contain a variety of pharmacologically active components that have shown to possess promising anti-diabetic potential. However, few data have been reported about medicinal plants from these regions in comparison to plants from other regions. Anti-diabetic medicinal plants from the MENA (the Middle East and North Africa) region, their role in controlling DM, and suggested mechanisms for the anti-diabetic activity of some medicinal plants are discussed in this review. Many of these plants have not been fully investigated and characterized, yet they have great potential for further development as anti-diabetic drugs.
\end{abstract}

\section{Implication for health policy/practice/research/medical education:}

This review provides up to date information on anti-diabetic medicinal plants from the Middle East and North Africa regions, many of which have not been fully investigated. This review will create a wide interest in these plants as potentially safe and effective anti-diabetic drugs for humans use in future.

Please cite this paper as: Abou Zekry SS, Badawy MT, Ezzelarab NM, Abdellatif A. Phytotherapy for diabetes mellitus; A review of Middle Eastern and North African folk medicinal plants. J Herbmed Pharmacol. 2021;10(1):1-13. doi: 10.34172/jhp.2021.01.

\section{Introduction}

Diabetes mellitus (DM) is a chronic metabolic disorder affecting people worldwide. According to the World Health Organization, there are currently 220 million people with type $2 \mathrm{DM}$, with expectations to increase to more than 365 million by 2030 . The highest increase in disease incidence is currently in undeveloped countries in Africa and Asia and herbal medicines are mostly investigated and used for this problem in these regions (1-4).

Type 1 diabetes is insulin-dependent, while type 2 or noninsulin dependent DM is treated with oral anti-diabetic medications $(4,5)$. Drugs used to treat type 2 diabetes are not without limitations (6); for example, Metformin and Glucagon-like peptide-1 agonists are associated with gastrointestinal distress (6). Sulfonylureas usually cause hypoglycemia and weight gain, while Pioglitazone may increase the possibility of developing bladder cancer and other disorders, such as edema, heart failure, weight gain, and distal bone fractures in postmenopausal women (6), in addition to the high cost of these medications. Therefore, patients seek other methods of treatment.

In low- and middle-income countries, patients rely on folk medicine as a cheaper alternative to modern pharmaceuticals. Phytomedicines or plant-based remedies are used worldwide to treat diabetes and other diseases. Many locally grown herbs have shown significant anti-diabetic effects in many countries $(7,8)$. Their main advantages are the low cost and lower levels of adverse effects and their ability to control blood glucose levels. Therefore, delaying the development of diabetic complications. Many of these herbs enhance insulin release, boost glucose uptake by muscle or adipose tissues, 
and reduce glucose absorption from the intestine and glucose yielding from the liver $(7,8)$.

Historically, plant extracts were prepared and used either orally, topically, or by vapor inhalation for managing diseases $(7,8)$. The Ancient Egyptians were the first to investigate the medicinal uses of castor oil, wine, opium, mints, and beer (7). In recent years, there has been an increasing interest in investigating the anti-diabetic effects of many medicinal plants, due to their wealth of biologically active material. This review aims to highlight the anti-diabetic effects of traditional plants cultivated in the Middle East and North Africa (MENA) region that has been recently used in research.

\section{Methods}

A comprehensive search using terms; Diabetes, phytotherapy, herbal medicine, folk medicine, in vivo, in vitro, and clinical trials yielded close to 20000 results spanning the period 1990 to 2020. The majority of the data available used plant extracts either in vitro or in vivo, with a minimal number $(<1 \%)$ of clinical trials using plant-based therapy present in the literature. We selected mainly plants cultivated in the MENA as the primary focus for our review.

\section{Phytoconstituents and their mechanisms of action}

Plant extracts exert their function due to the presence of a wide range of phytoconstituents or chemical compounds, each with a specific mechanism in reducing blood glucose or restoring it to normal levels (9). These compounds range from alkaloids, carbohydrates, anthranoids, flavonoids, saponins, amino acids, peptidoglycans, polyphenols, glycosides to vitamins, minerals, and inorganic compounds. Each constituent works on a specific metabolic pathway (9).

Among the most common phytoconstituents in plants are alkaloids, which are nitrogen-containing chemical compounds with a wide range of therapeutic potential. Many alkaloids exert their hypoglycemic activity as a result of having alpha-glucosidase (GLA) inhibiting activity (10). GLA catalyzes the cleavage of glucose from disaccharides and oligosaccharides. This inhibition will delay the absorption time of glucose by slowing the breakdown of starch in the small intestine so that glucose can slowly enter the bloodstream. Another alkaloid, allyl propyl disulfide from Allium sativum exerts its hypoglycemic effect through affecting glycogen synthesis (11). Mostly, this happens as a result of inhibiting lactate dehydrogenase enzyme. The enzyme catalyzes the conversion of pyruvate into lactate. Carbohydrates like pectin, pectin fibers, mucilaginous fibers and guar gum from Trigonella foenum graecum, as well as glucomannan, caryophyllene, cellulose, and mannose from Aloe vera, affect insulin secretion, absorption, and digestion of carbohydrates (12). Anthranoid compounds such as chrysophanic acid and cinnamic acid from Aloe vera possibly enhance insulin secretion and synthesis. C-glycosides from Trigonella foenum graecum lower glucose levels by targeting carbohydrate metabolism and glucose transport (13).

Flavonoids are present in a wide range of plants and are considered poly-hydroxy polyphenolic compounds (14). Flavonoids such as apigenin, quercitrin, quercetin, rutin, 7-O-glucoside, and naringenin from Camellia sinensis aid the restoration of pancreatic $\beta$-cells and enhance the secretion of insulin (14). Epigallocatechin gallate, epigallocatechin, epicatechin, catechin and quercetin from Camellia sinensis and Punica granatum have free radical scavenging and insulinemic activity $(14,15)$. Also, citrus bioflavonoids like hesperidin and naringin from Camellia sinensis target glycolysis, glycogen synthesis, and gluconeogenesis. Some peptidoglycans like Fenugreekine from Trigonella foenum graecum and glucosamines from Aloe vera are involved in glucose transport, carbohydrate digestion, and absorption (16). Sotolon and trigonelline extracted from Trigonella foenum graecum restore $\beta$ cells of the pancreas and enhance insulin secretion (16). Curcumin, turmerone, zingiberene, and germacrone from Curcuma longa also improve the metabolism of glucose.

Vitamins like A and E present in a range of plants might help in controlling glucose concentration (17). Minerals such as zinc from many plants like, for example, Aloe vera improves insulin sensitivity when present in high serum levels (18). Amino acids and carboxylic acid derivatives are among the phytoconstituents of medicinal value in diabetes. For example, leucine, isoleucine, and alanine from Aloe vera stimulate insulin secretion. Also, ferulic acid extracted from Curcuma longa boosts free radical scavenging activity and the secretion of insulin (19).

\section{MENA region anti-diabetic medicinal plants}

A map of the plants cultivated in the MENA region is shown in Figure 1. A distinction between the geographic locations is shown on the map. Below we summarize the most common anti-diabetic medicinal plants cultivated and used in the region together with the most recent reported data on in vitro and in vivo experimental models of DM in Table 1 (Middle East) and Table 2 (North Africa). Clinical studies of Middle Eastern and North African antidiabetic medicinal plants are shown in Table 3.

\section{Limitations of using anti-diabetic Middle Eastern and North African plants}

Despite the presence of previous research about many medicinal plants from both regions supporting their anti-diabetic effectiveness, some limitations might prevent the proper exploitation of these plants. Lack of standardization might be on the top of the main challenges that hinder the progress of utilizing the regions' medicinal plants. Variations in doses, anti-diabetic parameters, and 
North Africa

Anabasis articulate

Camellia sinensis

Capsicum annuum

Cinnamomum verum

Citrus limon

Curcuma longa

Daucus carota

Ficus carica

Phoenix dactylifera

Psidium guajava

Punica granatum

Rosmarinus officinalis

Solanum nigrum

Teucrium polium

Vitis vinifera

Zingiber officinale
Middle East

Acacia nilotica Achillea santolina Ajuga iva Alhagi maurorum Allium sativum Aloe vera Anastatica hierochuntica Artemisia judaica Asparagus stipularis Capparis spinosa Citrullus colocynthis Cleome droserifolia Ephedra alata Lepidium sativum Lycium shawii Ricinus communis Salvia aegyptiaca Silybum marianum

Figure 1. Map showing MENA region anti-diabetic medicinal plants.

duration of therapy make it challenging to determine the medicinal plant with the best reported anti-diabetic effect (20). Moreover, previous reports demonstrated that lack of data exchange among traditional herbal practitioners and between practitioners and researches might represent a threat in utilizing these plants (7). Another challenge facing the utilization of anti-diabetic plants is the continuous destruction of the plants' natural habitat as a result of climate as well as environmental changes leaving many endangered species facing the possibility of extinction in the coming few years (7).

\section{Discussion and future perspectives}

Plant-derived products in the global market are provided mainly from either Chinese, Indian, and Western plants. In comparison to plants from other regions, like China or India, medicinal plants from the MENA region have never been adequately investigated, explored, evaluated, or exploited. Extensive research is needed to fill the gap in information concerning safety, toxicity, contamination, possible interaction with other synthetic drugs, and proper dosage $(8,20,21)$. Chinese traditional medicine is successfully promoted via a science-based approach. The great effort and financial support that has been put by China was evident by 3563 extracts, 64715 compositions, and 130 kinds of Chinese herbs-derived drugs under development. Other countries and or regions could adopt this successful approach in utilizing and promoting traditional medicine to take advantage of their herbal heritage.

This review provides a summary of the anti-diabetic role of some typical Middle Eastern and North African medicinal plants through previous experiments done in vitro, in vivo, and clinical trials. From the collected data, medicinal plants from both regions not only hold a remarkable hypoglycemic potential but also help to delay the development and progression of complications through their antioxidant, hepatoprotective, renalprotective, and anti-hyperlipidemic effects.

Most In vitro studies investigated the effects of plants on the enzymes; Alpha-amylase (ALA) and GLA. The inhibition of ALA activity, together with GLA, is considered to be a successful strategy for the management of diabetes. Both ALA, which breaks down long-chain carbohydrates and GLA, which catalyzes glucose cleavage from disaccharide, is effective in delaying glucose absorption (22). In our review, in vitro GLA and ALA inhibition were consistent with exhibiting hypoglycemic effects in vivo in almost all plants included. However, plants like $A$. santolina and T. polium, did not inhibit GLA and ALA in vitro, although showing an anti-diabetic effect in vivo. It can be suggested that they exert their hypoglycemic effect by mechanisms other than lowering these enzymes. Time and money-saving computational chemistry tools like molecular modeling and molecular docking allow for the prediction of molecule's inhibition actions of enzymes. For example, molecules from Rosemary and Salvia can inhibit the dipeptidyl peptidase 4 (DDP4) enzyme, which is involved in the treatment of type $2 \mathrm{DM}$ (23).

Animal studies in this review investigated an array of parameters to address the anti-diabetic potential of medicinal plants. Improving these parameters is essential to demonstrate efficacy. Together with fasting blood glucose (FBG) and serum insulin levels, liver parameters like alanine aminotransferase (ALT), aspartate aminotransferase (AST), and gamma glutamyl transferase $(\gamma \mathrm{GT})$ were used to estimate hepatocyte injury. It is suggested that hyperglycemia promotes the accumulation 
Table 1. Summary of in vitro, in vivo animal studies showing the anti-diabetic effect of plants cultivated in the Middle East region

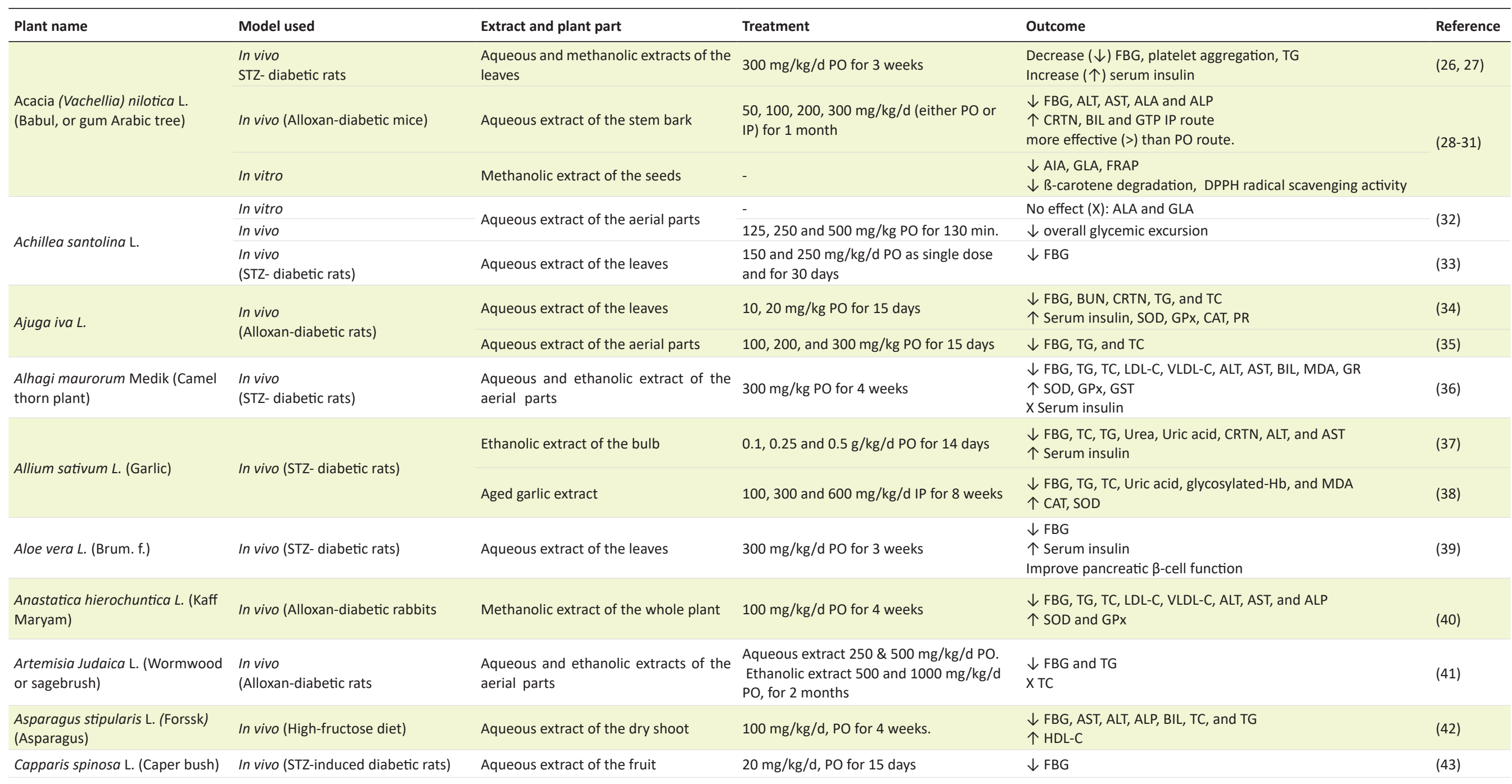


Table 1. Continued

\begin{tabular}{|c|c|c|c|c|c|}
\hline Plant name & Model used & Extract and plant part & Treatment & Outcome & Reference \\
\hline \multirow{2}{*}{$\begin{array}{l}\text { Citrullus Colocynthis L. (Schrad) } \\
\text { (Bitter Apple) }\end{array}$} & In vivo (STZ-induced diabetic rats) & Petroleum ether extract of the fruit & 300 and $500 \mathrm{mg} / \mathrm{kg} / \mathrm{d} \mathrm{PO}$ for 14 days & $\begin{array}{l}\downarrow \text { FBG } \\
\downarrow \text { TBARS }\end{array}$ & \multirow{2}{*}{$(44-48)$} \\
\hline & In vivo (Alloxan-diabetic rats & Aqueous extract of the leaves & $250 \& 500 \mathrm{mg} / \mathrm{kg} / \mathrm{d} \mathrm{PO}$ for 60 days & $\begin{array}{l}\downarrow \text { FBG, Gly-Hb, G6P, and FBPase } \\
\uparrow \text { Liver hexokinase }\end{array}$ & \\
\hline $\begin{array}{l}\text { Cleome droserifolia L. (Spider } \\
\text { flower) }\end{array}$ & In vivo (Alloxan-diabetic rats & $\begin{array}{l}\text { Methanolic extract of the stem and the } \\
\text { leaves }\end{array}$ & $310 \mathrm{mg} / \mathrm{kg} / \mathrm{d}$ PO for 30 days & $\begin{array}{l}\downarrow \text { FBG, TG, TC, LDL-C, AST, and ALT, Urea, and CRTN } \\
\uparrow \text { Serum insulin and HLDL-C }\end{array}$ & $(49,50)$ \\
\hline Ephedra alata Decne & In vivo (Alloxan-diabetic rats & Aqueous extract of the aerial parts & 100,200 , and $300 \mathrm{mg} / \mathrm{kg} / \mathrm{d}$ PO for 28 days & $\begin{array}{l}\downarrow \text { FBG, TG, TC, LDL-C, amylase, lipase, MDA and PC } \\
\uparrow ~ H L D L-C, \text { SOD, CAT, and GPx }\end{array}$ & (51) \\
\hline $\begin{array}{l}\text { Lepidium } \\
\text { Sativum L. (Garden Cress) }\end{array}$ & $\begin{array}{l}\text { In vivo } \\
\text { (STZ- diabetic rats) }\end{array}$ & Aqueous extract of the seeds & $\begin{array}{l}20 \mathrm{mg} / \mathrm{kg} / \mathrm{d} \text { PO as acute (single dose) and } \\
\text { chronic treatment (for } 15 \text { days) }\end{array}$ & $\begin{array}{l}\downarrow \text { FBG in acute and chronic treatment } \\
X \text { Serum insulin }\end{array}$ & (52) \\
\hline $\begin{array}{l}\text { Lycium shawii Roem. \& Schult. } \\
\text { (Desert thorn) }\end{array}$ & $\begin{array}{l}\text { In vivo } \\
\text { (STZ- diabetic rats) }\end{array}$ & $\begin{array}{l}\text { Ethanolic extract }(80 \%) \text { of the aerial } \\
\text { parts }\end{array}$ & $500 \mathrm{mg} / \mathrm{kg} / \mathrm{d} \mathrm{PO}$ and $\mathrm{IP}$ & $\downarrow$ FBG & $(53,54)$ \\
\hline \multirow[t]{2}{*}{$\begin{array}{l}\text { Salvia aegyptiaca L. (Egyptian } \\
\text { sage) }\end{array}$} & $\begin{array}{l}\text { In vivo } \\
\text { (STZ- diabetic rats) }\end{array}$ & $\begin{array}{l}\text { Methanolic and hydroethanolic extracts } \\
\text { of the whole plant }\end{array}$ & $\begin{array}{l}500,1000,1500 \text {, and } 2000 \mathrm{mg} / \mathrm{kg} / \mathrm{d} \mathrm{PO} \\
\text { for } 14 \text { days }\end{array}$ & $\begin{array}{l}\downarrow \text { FBG, TG, TC, LDL-C, VLDL-C, AST, ALT, ALP } \\
\uparrow \text { HLDL-C } \\
\text { Improve the appearance of pancreatic islets histologically }\end{array}$ & (55) \\
\hline & Computational (molecular docking) & - & - & $\downarrow$ Dipeptidyl peptidase 4 (DPP-4) enzyme & (23) \\
\hline
\end{tabular}

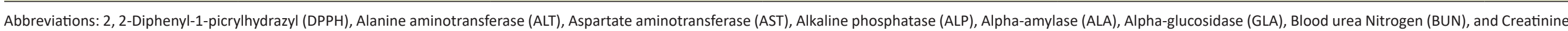

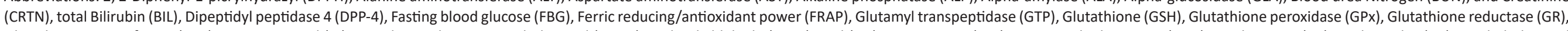

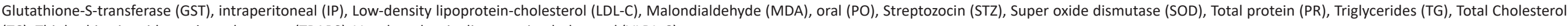

(TC), Thiobarbituric acid reactive substances (TBARS), Very low-density lipoprotein-cholesterol (VLDL-C).

$\downarrow$ : decrease, $\uparrow:$ increase, $X:$ no effect, >: more effective. 
Table 2. Summary of in vitro, in vivo animal studies showing the anti-diabetic effect of plants that are cultivated in the North African region

\begin{tabular}{|c|c|c|c|c|c|}
\hline Plant Name & Model used & Plant part \& extract preparation & Treatment & Outcome & References \\
\hline $\begin{array}{l}\text { Anabasis articulata } \\
\text { (Forssk.) }\end{array}$ & In vivo, STZ-induced diabetic rats & $\begin{array}{l}\text { Ethanolic and petroleum ether } \\
\text { extract of the aerial parts }\end{array}$ & $400 \mathrm{mg} / \mathrm{kg} / \mathrm{d}$ PO for 1 month & $\begin{array}{l}\text { Decrease }(\downarrow) \text { FBG, cortisol, and TNF- } \alpha \\
\text { Increase }(\uparrow) \text { Serum insulin and } \alpha \text { - fetoprotein }\end{array}$ & (57) \\
\hline $\begin{array}{l}\text { Camellia sinensis (L.) } \\
\text { Kuntze (tea shrub) }\end{array}$ & In vivo (STZ-induced diabetic rats) & Ethanolic extract of the leaves & $100,200 \mathrm{mg} / \mathrm{Kg}$ PO for 4 weeks & $\downarrow$ FBG, serum and hepatic MDA; $\uparrow$ TAC & (58) \\
\hline \multirow{3}{*}{$\begin{array}{l}\text { Capsicum annuum } L . \\
\text { (Peppers) }\end{array}$} & In vitro & \multirow{2}{*}{ Aqueous extract of the leaves } & - & $\downarrow A L A$ and GLA & \multirow{2}{*}{ (59) } \\
\hline & In vivo (STZ-induced diabetic rats) & & 100,200 and $300 \mathrm{mg} / \mathrm{kg} \mathrm{PO}$ & $\downarrow F B G$ & \\
\hline & In vivo (STZ-induced diabetic rats) & Ethanolic extract of the fruit & $300 \mathrm{mg} / \mathrm{kg} / \mathrm{d}$ PO for 4 weeks & $\begin{array}{l}\downarrow \text { FBG, ALT, ALP, Urea, CRTN and CKMB and HOMA-IR } \\
\uparrow \text { Serum insulin and } \uparrow \text { HOMA- } \beta\end{array}$ & $(60)$ \\
\hline $\begin{array}{l}\text { Cinnamomum Verum } \\
\text { J.Presl (Cinnamon) }\end{array}$ & In vivo (Alloxan-induced diabetic rat models) & Aqueous extract of the bark & $\begin{array}{l}200,400,600 \text { and } 1200 \mathrm{mg} / \mathrm{kg} / \mathrm{d} \text { PO for } \\
1 \text { month }\end{array}$ & $\downarrow F B G$ & $(61)$ \\
\hline \multirow{3}{*}{$\begin{array}{l}\text { Citrus limon (L.) Osbeck } \\
\text { (Lemon) }\end{array}$} & In vivo (Alloxan-induced diabetic rat models) & Hexane extract of the peel & $10 \mathrm{mg} / \mathrm{kg} / \mathrm{d}$ PO for 4 days & $\downarrow$ FBG; $\uparrow$ Serum insulin & (62) \\
\hline & In vitro & $\begin{array}{l}\text { Essential oil of the peel obtained by } \\
\text { hydrodistillation }\end{array}$ & - & $\downarrow A L A$ and GLA & $(63)$ \\
\hline & In vivo (Alloxan-induced diabetic rat models) & Aqueous extract of the peel & $100,200,300 \mathrm{mg} / \mathrm{kg} / \mathrm{d}$ PO for 14 days & $\downarrow \mathrm{FBG}$ & (64) \\
\hline \multirow{2}{*}{$\begin{array}{l}\text { Curcuma longa } \mathrm{L} . \\
\text { (Turmeric) }\end{array}$} & In vivo (STZ- induced diabetic rats) & Methanolic extract of the rhizomes & $\begin{array}{l}100 \mathrm{mg} / \mathrm{kg} \text { twice weekly, } 250 \mathrm{mg} / \mathrm{kg} \text { twice } \\
\text { weekly, } 500 \mathrm{mg} / \mathrm{kg} / \mathrm{d} \text { PO }\end{array}$ & $\begin{array}{l}\downarrow \text { FBG, CRTN } \\
\uparrow \text { Serum uric acid. Low dose improved ALT, AST, High dose and } \\
\text { PO: } \uparrow \text { ALT \& AST. Islet cell and renal tissue protection. Limited } \\
\text { protection of Liver tissue. }\end{array}$ & $(65,66)$ \\
\hline & In vitro & $\begin{array}{l}\text { Methanolic extract of the rhizomes } \\
\text { (Comparing the effects of the } 3 \\
\text { Curcuminoids (BDMC, Curcumin and } \\
\text { DMC) }\end{array}$ & - & $\begin{array}{l}\downarrow \mathrm{GLA} \\
(\mathrm{BDMC}>\text { Curcumin }>\mathrm{DMC})\end{array}$ & $(67)$ \\
\hline $\begin{array}{l}\text { Daucus carota L. (Wild } \\
\text { carrot) }\end{array}$ & In vivo (STZ- induced diabetic rats) & Methanolic extract of the seeds & 100,200 and $300 \mathrm{mg} / \mathrm{kg} / \mathrm{d}$ PO for 6 days & $\downarrow$ FBG; Serum insulin & (68) \\
\hline \multirow{2}{*}{ Ficus carica L. (Fig) } & In vivo (STZ-induced diabetic rats) & Aqueous extract of the stem bark & $500 \mathrm{mg} / \mathrm{kg} / \mathrm{d}$ PO for 21 days & $\begin{array}{l}\downarrow \text { FBG, TG, and TC, LDL-C, and VLDL-C } \\
\uparrow \text { Serum insulin and HDL-C }\end{array}$ & $(69)$ \\
\hline & $\begin{array}{l}\text { In vivo (High glucose diet induced-diabetic } \\
\text { rats) }\end{array}$ & $\begin{array}{l}\text { Aqueous extract of the leaf, peel, } \\
\text { and pulp }\end{array}$ & 50 and $100 \mathrm{mg} / \mathrm{kg} / \mathrm{d}$ for 56 days & $\downarrow$ FBG; $\uparrow$ Serum insulin & (70) \\
\hline $\begin{array}{l}\text { Phoenix dactylifera L. } \\
\text { (Date) }\end{array}$ & $\begin{array}{l}\text { In vivo } \\
\text { (Alloxan-induced diabetic mice) }\end{array}$ & $\begin{array}{l}\text { Aqueous and Ethanolic extracts of } \\
\text { the leaves }\end{array}$ & $20 \mathrm{mg} / \mathrm{kg} / \mathrm{d}$ PO for 28 days & $\downarrow$ FBG & (71) \\
\hline Psidium guajava L. (Guava) & In vivo (High fat diet-induced diabetic mice) & Ethanolic extract of guava leaves & $\begin{array}{l}5 \mathrm{mg} / \mathrm{kg} \text { daily } \\
\text { by oral gavage for } 7 \text { weeks }\end{array}$ & $\begin{array}{l}\downarrow \text { FBG, TG, TC, LDL: HDL ratio and HOMA-IR } \\
X \text { LDL-C and weight gain } \\
\uparrow \text { Endothelial functions }\end{array}$ & $(72)$ \\
\hline \multirow{2}{*}{$\begin{array}{l}\text { Punica granatum L. } \\
\text { (Pomegranate) }\end{array}$} & In vivo (Alloxan-induced diabetic rats) & $\begin{array}{l}\text { No extract (crude husk powder was } \\
\text { used) }\end{array}$ & $1000 \mathrm{mg} / \mathrm{kg} / \mathrm{d}$ PO for 10 days & $\begin{array}{l}\downarrow \text { FBG, Hb content and HDL-C } \\
\downarrow \mathrm{TG}, \mathrm{TC}, \mathrm{LDL}-\mathrm{C}, \mathrm{VLDL}-\mathrm{C} \text {, and Gly-Hb}\end{array}$ & $(73)$ \\
\hline & In vivo (STZ-induced diabetic rats) & $\begin{array}{l}\text { Aqueous and ethanolic extracts of } \\
\text { the flower }\end{array}$ & 200 and $400 \mathrm{mg} / \mathrm{kg} / \mathrm{d}$ PO for 1 month & $\begin{array}{l}\downarrow \text { FBG, TG, TC, LDL-C, VLDL-C, Gly-Hb, TBARS and G6P } \\
\text { 个 SOD, GPx and CAT }\end{array}$ & $(74)$ \\
\hline
\end{tabular}




\begin{tabular}{|c|c|c|c|c|c|}
\hline Plant Name & Model used & Plant part \& extract preparation & Treatment & Outcome & References \\
\hline \multirow{2}{*}{$\begin{array}{l}\text { Rosmarinus officinalis } \\
\text { (Salvia rosmarinus Spenn.) } \\
\text { (Rosemary) }\end{array}$} & In vivo (STZ-induced diabetic rats) & Aqueous extract of the leaves & $200 \mathrm{mg} / \mathrm{kg} / \mathrm{d}$ PO for 21 days & $\begin{array}{l}\downarrow \text { FBG, TG, and TC } \\
\uparrow \text { TAC, amylase, and TP }\end{array}$ & (75) \\
\hline & Computational (molecular docking) & - & - & $\downarrow$ DPP-4 enzyme & (23) \\
\hline \multirow{3}{*}{$\begin{array}{l}\text { Solanum nigrum L. (Black } \\
\text { nightshade) }\end{array}$} & In vivo Normal albino rats & $\begin{array}{l}\text { Ethanolic extract of the whole plant } \\
\text { except the roots }\end{array}$ & $250 \mathrm{mg} / \mathrm{kg} / \mathrm{d}$ PO for 1 week & $\downarrow$ FBG & (76) \\
\hline & In vivo (Alloxan-diabetic rats) & Silymarin $(50 \mathrm{~g} / \mathrm{mg})$ solution & $40 \mathrm{mg} / \mathrm{kg} / \mathrm{d}$ P.O for 6 weeks & $\begin{array}{l}\downarrow \text { FBG, Gly-Hb, and LPO } \\
\text { Improve the appearance of pancreatic islets histologically }\end{array}$ & (76) \\
\hline & In vivo (Alloxan-diabetic guinea pigs & Aqueous extract of the leaves & $200 \mathrm{mg} / \mathrm{kg} / \mathrm{d}$ PO for 28 days & $\downarrow$ FBG & (77) \\
\hline \multirow{4}{*}{$\begin{array}{l}\text { Teucrium polium L. } \\
\text { (Golden germander) }\end{array}$} & In vivo (STZ-induced diabetic rats) & Aqueous extract of the aerial parts & $500 \mathrm{mg} / \mathrm{kg} / \mathrm{d}$ PO for 6 weeks & $\downarrow$ FBG; $\uparrow$ Serum insulin & (78) \\
\hline & In vitro & \multirow[b]{2}{*}{ Aqueous extract of the aerial parts } & - & X ALA and GLA & \multirow[b]{2}{*}{ (32) } \\
\hline & In vivo (Starch-induced diabetic rats) & & 125,250 , and $500 \mathrm{mg} / \mathrm{kg}$ PO for $130 \mathrm{~min}$. & $\begin{array}{l}\text { X Overall glycemic excursions } \\
\downarrow \text { FBG } 45 \text { min post starch administration }\end{array}$ & \\
\hline & In vivo (Normoglycemic rats & Aqueous extract of the aerial parts & $100 \mathrm{mg} / \mathrm{kg} / \mathrm{d}$ for $210 \mathrm{~min}$ & $\downarrow$ FBG at different 30, 60, 90 120, 180, and $210 \mathrm{~min}$ & (25) \\
\hline \multirow{2}{*}{$\begin{array}{l}\text { Vitis vinifera } \mathrm{L} . \\
\text { (Grape vine) }\end{array}$} & In vivo (STZ-induced diabetic rats) & Aqueous extract of the leaves & $250,500 \mathrm{mg} / \mathrm{kg}$ PO for 14 days & $\begin{array}{l}\downarrow \text { FBG, body weight, and MDA } \\
\uparrow \mathrm{GSH}\end{array}$ & (79) \\
\hline & In vivo (Alloxan-induced diabetic rats) & Aqueous extract of grape skin & $200 \mathrm{mg} / \mathrm{kg} / \mathrm{d}$ PO for 19 days & $\begin{array}{l}\downarrow F B G \text { and insulin resistance, antioxidant effect } \\
\uparrow \text { insulin-signaling cascade }\end{array}$ & (80) \\
\hline \multirow{3}{*}{$\begin{array}{l}\text { Zingiber officinale Roscoe } \\
\text { (ginger) }\end{array}$} & In vitro & Ethyl acetate extract of the root & - & $\downarrow A L A$ and GLA & (82) \\
\hline & In vivo (Alloxan-induced diabetic rats) & Aqueous extract of the root & $500 \mathrm{mg} / \mathrm{kg} / \mathrm{d}$ PO for 6 weeks & $\downarrow F B G$ & (83) \\
\hline & In vitro & Ethyl acetate extract of the rhizomes & - & $\downarrow$ LDL oxidation; $\uparrow$ Glucose uptake & (84) \\
\hline
\end{tabular}

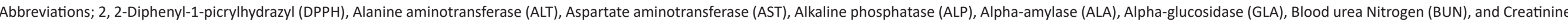

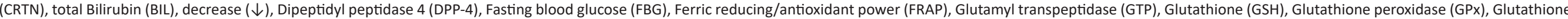

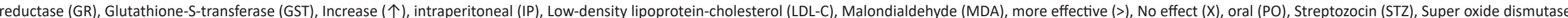

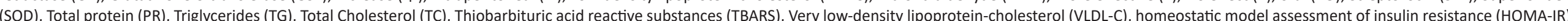

$\downarrow$ : decrease, $\uparrow:$ increase, $X$ : no effect. 
Table 3. Summary of clinical trials showing the anti-diabetic potential of plants cultivated in the Middle East and North Africa regions

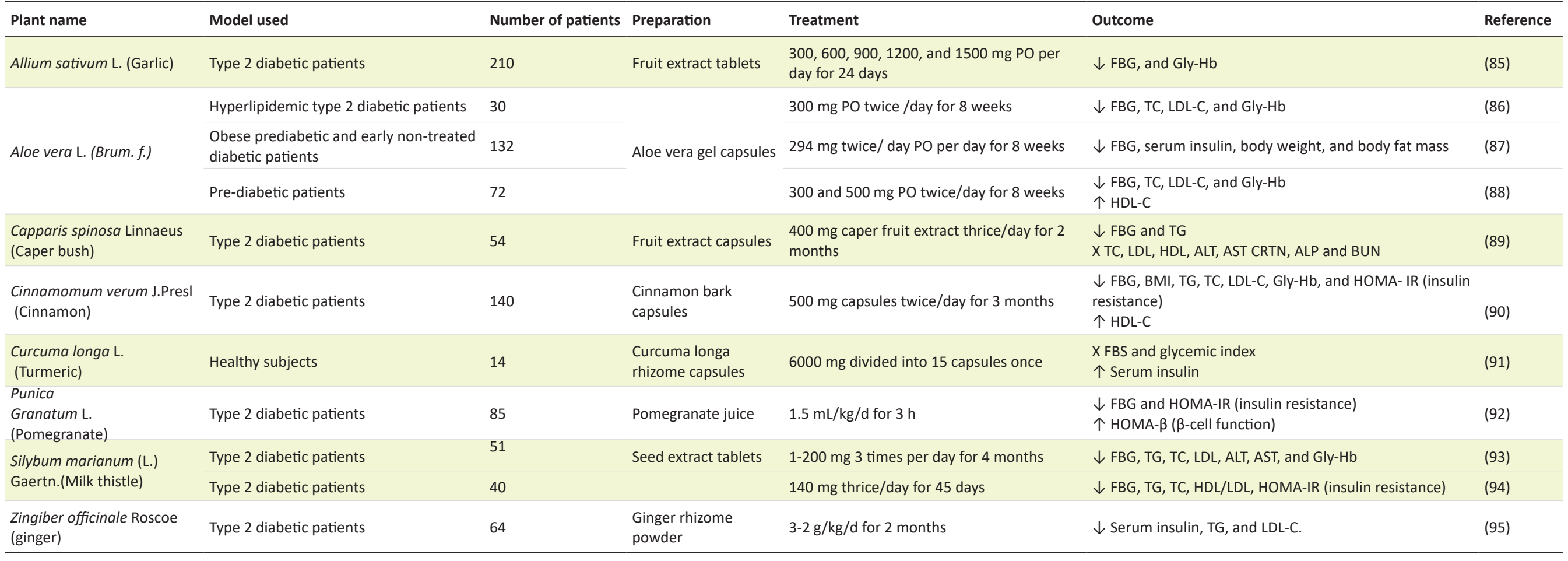

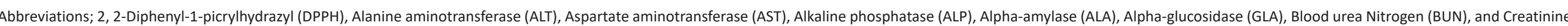

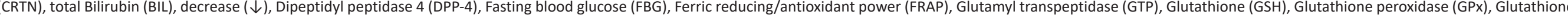

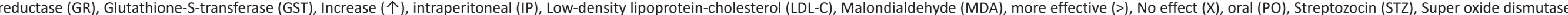
(SOD), Total protein (PR), Triglycerides (TG), Total Cholesterol (TC), Thiobarbituric acid reactive substances (TBARS), Very low-density lipoprotein-cholesterol (VLDL-C).

$\downarrow:$ decrease, $\uparrow:$ increase, $X:$ no effect 
of reactive oxygen species, accelerates cell damage, and contributes to the development and worsening of diabetic complications. Blood urea, creatinine (CRTN), and uric acid levels are indications of the kidney damage associated with hyperglycemia-caused oxidative stress. Among the investigated parameters is homeostatic model assessment of insulin resistance (HOMA-IR), which is used for the assessment of insulin resistance (24). It is suggested that hyperglycemia leads to insulin resistance in peripheral tissues as a result of the impairment of insulin secretion and sensitivity (24). Antioxidant parameters like super oxide dismutase (SOD) and glutathione peroxidase (GPx) were used to assess the antioxidant potential. Interestingly, anti-diabetic plants may contribute to protection against developing DM, as shown in some clinical trials. For example, A. vera delayed the onset of the disease in prediabetic patients (Table 3 ).

In conclusion, more investigations are needed to utilize medicinal plants from these regions as a source of future drugs that contribute to managing the disease more efficiently than current medications. For example, T. polium, which is grown in the Mediterranean region, showed potent glucose-lowering activity similar to insulin in one study. However, the exact hypoglycemic agents and their mechanisms of action are yet to be identified (25). That is why more research should be directed towards understanding the mechanisms responsible for the anti-diabetic activity of many plants. Finding ways to circumvent the limitations of utilizing medicinal plants is essential. A database of medicinal plants in both regions showing critical data such as usage parameters, safety, toxicity, contamination, and drug interactions might help face limitations. Pharmaceutical companies, together with government authorities, should help to provide more research and start initiatives to spread awareness among traditional practitioners and to protect endangered medicinal plant species from extinction, which will eventually pave the way for using the regions' medicinal plants commercially.

\section{Authors' contribution}

$\mathrm{SA}, \mathrm{MB}, \mathrm{NE}$ contributed in designing the study, performed data collection and manuscript preparation. AA supervised and edited the manuscript. Final version of the manuscript was confirmed by all authors. SA, MB, NE contributed equally

\section{Conflict of interests}

The authors declare no conflict of interest.

\section{Ethical considerations}

No ethical approval was required for this review article

\section{Funding/Support}

This work was partially supported by a research support grant (SSE-BIOL-A.A-FY17-RG-2018) from the American university in Cairo.

\section{References}

1. Maiti R, Jana D, Das UK, Ghosh D. Antidiabetic effect of aqueous extract of seed of Tamarindus indica in streptozotocin-induced diabetic rats. J Ethnopharmacol. 2004;92(1):85-91. doi: 10.1016/j.jep.2004.02.002.

2. Shahbazian H. World diabetes day; 2013. J Renal Inj Prev. 2013;2(4):123-4. doi: 10.12861/jrip.2013.39.

3. Shahbazian H, Rezaii I. Diabetic kidney disease; review of the current knowledge. J Renal Inj Prev. 2013;2(2):73-80. doi: 10.12861/jrip.2013.24.

4. Nazarian-Samani Z, Sewell RDE, Lorigooini Z, RafieianKopaei M. Medicinal plants with multiple effects on diabetes mellitus and its complications: a systematic review. Curr Diab Rep. 2018;18(10):72. doi: 10.1007/ s11892-018-1042-0.

5. Oh WK, Lee CH, Lee MS, Bae EY, Sohn CB, Oh H, et al. Antidiabetic effects of extracts from Psidium guajava. J Ethnopharmacol. 2005;96(3):411-5. doi: 10.1016/j. jep.2004.09.041.

6. Valerón PF, de Pablos-Velasco PL. [Limitations of insulindependent drugs in the treatment of type 2 diabetes mellitus]. Med Clin (Barc). 2013;141 Suppl 2:20-5. doi: 10.1016/s0025-7753(13)70059-9.

7. Azaizeh H, Saad B, Khalil K, Said O. The state of the art of traditional Arab herbal medicine in the Eastern region of the Mediterranean: a review. Evid Based Complement Alternat Med. 2006;3(2):229-35. doi: 10.1093/ecam/ nel034.

8. Saad B, Azaizeh H, Abu-Hijleh G, Said O. Safety of traditional Arab herbal medicine. Evid Based Complement Alternat Med. 2006;3(4):433-9. doi: 10.1093/ecam/nel058.

9. Bharti SK, Krishnan S, Kumar A, Kumar A. Antidiabetic phytoconstituents and their mode of action on metabolic pathways. Ther Adv Endocrinol Metab. 2018;9(3):81-100. doi: $10.1177 / 2042018818755019$.

10. Torre-Bouscoulet ME, López-Romero E, BalcázarOrozco R, Calvo-Méndez C, Flores-Carreón A. Partial purification and biochemical characterization of a soluble alpha-glucosidase II-like activity from Candida albicans. FEMS Microbiol Lett. 2004;236(1):123-8. doi: 10.1016/j. femsle.2004.05.033.

11. Sheela CG, Kumud K, Augusti KT. Anti-diabetic effects of onion and garlic sulfoxide amino acids in rats. Planta Med. 1995;61(4):356-7. doi: 10.1055/s-2006-958099.

12. Venkatesan N, Devaraj SN, Devaraj H. Increased binding of LDL and VLDL to apo B, E receptors of hepatic plasma membrane of rats treated with Fibernat. Eur J Nutr. 2003;42(5):262-71. doi: 10.1007/s00394-003-0420-8.

13. Gupta D, Raju J, Baquer NZ. Modulation of some gluconeogenic enzyme activities in diabetic rat liver and kidney: effect of antidiabetic compounds. Indian J Exp Biol. 1999;37(2):196-9.

14. Waltner-Law ME, Wang XL, Law BK, Hall RK, Nawano M, Granner DK. Epigallocatechin gallate, a constituent of green tea, represses hepatic glucose production. J 
Biol Chem. 2002;277(38):34933-40. doi: 10.1074/jbc. M204672200.

15. Vessal M, Hemmati M, Vasei M. Antidiabetic effects of quercetin in streptozocin-induced diabetic rats. Comp Biochem Physiol C Toxicol Pharmacol. 2003;135C(3):35764. doi: 10.1016/s1532-0456(03)00140-6.

16. Khosla P, Gupta DD, Nagpal RK. Effect of Trigonella foenum graecum (Fenugreek) on blood glucose in normal and diabetic rats. Indian J Physiol Pharmacol. 1995;39(2):173-4.

17. Bharti SK, Krishnan S, Kumar A, Rajak KK, Murari K, Bharti BK, et al. Antidiabetic activity and molecular docking of fructooligosaccharides produced by Aureobasidium pullulans in poloxamer-407-induced T2DM rats. Food Chem. 2013;136(2):813-21. doi: 10.1016/j.foodchem.2012.08.083.

18. Wijesekara N, Chimienti F, Wheeler MB. Zinc, a regulator of islet function and glucose homeostasis. Diabetes Obes Metab. 2009;11 Suppl 4:202-14. doi: 10.1111/j.14631326.2009.01110.x.

19. Ohnishi M, Matuo T, Tsuno T, Hosoda A, Nomura E, Taniguchi $\mathrm{H}$, et al. Antioxidant activity and hypoglycemic effect of ferulic acid in STZ-induced diabetic mice and KK-Ay mice. Biofactors. 2004;21(1-4):315-9. doi: 10.1002/biof.552210161.

20. Teugwa CM, Boudjeko T, Tchinda BT, Mejiato PC, Zofou D. Anti-hyperglycaemic globulins from selected Cucurbitaceae seeds used as antidiabetic medicinal plants in Africa. BMC Complement Altern Med. 2013;13:63. doi: $10.1186 / 1472-6882-13-63$.

21. Teugwa CM, Mejiato PC, Zofou D, Tchinda BT, Boyom FF. Antioxidant and antidiabetic profiles of two African medicinal plants: Picralima nitida (Apocynaceae) and Sonchus oleraceus (Asteraceae). BMC Complement Altern Med. 2013;13:175. doi: 10.1186/1472-6882-13-175.

22. Yu L, Nie $X$, Pan $H$, Ling S, Zhang $D$, Bian $K$. [Diabetes mellitus ulcers treatment with Bletilla striata polysaccharide]. Zhongguo Zhong Yao Za Zhi. 2011;36(11):1487-91.

23. Salim B, Hocine A, Said G. First study on anti-diabetic effect of rosemary and salvia by using molecular docking. J Pharm Res Int. 2017;19(4):1-12. doi: 10.9734/ jpri/2017/37061.

24. Antuna-Puente B, Disse E, Rabasa-Lhoret R, Laville M, Capeau J, Bastard JP. How can we measure insulin sensitivity/resistance? Diabetes Metab. 2011;37(3):17988. doi: 10.1016/j.diabet.2011.01.002.

25. Caccetta R, Ireng A, Helmerhorst E, Parsons R. Teucrium polium significantly lowers blood glucose levels acutely in normoglycemic male Wistar rats: a comparative to insulin and metformin. Adv Med Plant Res. 2016;4(1):1-10.

26. Asad M, Aslam M, Munir TA, Nadeem A. Effect of Acacia nilotica leaves extract on hyperglycaemia, lipid profile and platelet aggregation in streptozotocin induced diabetic rats. J Ayub Med Coll Abbottabad. 2011;23(2):3-7.

27. Asad M, Munir TA, Afzal N. Acacia nilotica leave extract and glyburide: comparison of fasting blood glucose, serum insulin, beta-thromboglubulin levels and platelet aggregation in streptozotocin induced diabetic rats. J Pak Med Assoc. 2011;61(3):247-51.
28. Omara EA, Nada SA, Farrag AR, Sharaf WM, El-Toumy SA. Therapeutic effect of Acacia nilotica pods extract on streptozotocin induced diabetic nephropathy in rat. Phytomedicine. 2012;19(12):1059-67. doi: 10.1016/j. phymed.2012.07.006.

29. Abuelgassim AO. Effect of Acacia nilotica fruit extract on serum glucose and lipid concentrations in alloxaninduced diabetic rats. Pak J Biol Sci. 2013;16(21):1398402. doi: 10.3923/pjbs.2013.1398.1402.

30. Roozbeh N, Darvish L, Abdi F. Hypoglycemic effects of Acacia nilotica in type II diabetes: a research proposal. BMC Res Notes. 2017;10(1):331. doi: 10.1186/s13104017-2646-1.

31. Saha MR, Dey P, Sarkar I, De Sarker D, Haldar B, Chaudhuri TK, et al. Acacia nilotica leaf improves insulin resistance and hyperglycemia associated acute hepatic injury and nephrotoxicity by improving systemic antioxidant status in diabetic mice. J Ethnopharmacol. 2018;210:275-86. doi: 10.1016/j.jep.2017.08.036.

32. Kasabri V, Afifi FU, Hamdan I. In vitro and in vivo acute antihyperglycemic effects of five selected indigenous plants from Jordan used in traditional medicine. J Ethnopharmacol. 2011;133(2):888-96. doi: 10.1016/j. jep.2010.11.025.

33. Yazdanparast R, Ardestani A, Jamshidi S. Experimental diabetes treated with Achillea santolina: effect on pancreatic oxidative parameters. J Ethnopharmacol. 2007;112(1):13-8. doi: 10.1016/j.jep.2007.01.030.

34. Wang JJ, Jin $\mathrm{H}$, Zheng SL, Xia P, Cai Y, Ni XJ. Phytoecdysteroids from Ajuga iva act as potential antidiabetic agent against alloxan-induced diabetic male albino rats. Biomed Pharmacother. 2017;96:480-8. doi: 10.1016/j.biopha.2017.10.029.

35. El Hilaly J, Lyoussi B. Hypoglycaemic effect of the lyophilised aqueous extract of Ajuga iva in normal and streptozotocin diabetic rats. J Ethnopharmacol. 2002;80(23):109-13. doi: 10.1016/s0378-8741(01)00407-x.

36. Sheweita SA, Mashaly S, Newairy AA, Abdou HM, Eweda SM. Changes in oxidative stress and antioxidant enzyme activities in streptozotocin-induced diabetes mellitus in rats: role of Alhagi maurorum extracts. Oxid Med Cell Longev. 2016;2016:5264064. doi: 10.1155/2016/5264064.

37. Eidi A, Eidi M, Esmaeili E. Antidiabetic effect of garlic (Allium sativum L.) in normal and streptozotocininduced diabetic rats. Phytomedicine. 2006;13(9-10):6249. doi: 10.1016/j.phymed.2005.09.010.

38. Al-Qattan MM, Al-Habib A, Alshomer F, Bagayawa R, Ahmed D, Al-Nafisah G, et al. The use of recombinant nAG protein in spinal cord crush injury in a rat model. J Coll Physicians Surg Pak. 2017;27(6):356-61.

39. Noor A, Gunasekaran S, Vijayalakshmi MA. Improvement of insulin secretion and pancreatic $\beta$-cell function in streptozotocin-induced diabetic rats treated with Aloe vera extract. Pharmacognosy Res. 2017;9(Suppl 1):S99-S104. doi: 10.4103/pr.pr_75_17.

40. Al-Azzawie HF, Alhamdani MS. Hypoglycemic and antioxidant effect of oleuropein in alloxan-diabetic rabbits. Life Sci. 2006;78(12):1371-7. doi: 10.1016/j. lfs.2005.07.029.

41. Ahmad W, Khan I, Khan MA, Ahmad M, Subhan F, Karim 
N. Evaluation of antidiabetic and antihyperlipidemic activity of Artemisia indica linn (aeriel parts) in Streptozotocin induced diabetic rats. J Ethnopharmacol. 2014;151(1):618-23. doi: 10.1016/j.jep.2013.11.012.

42. Adouni K, Chahdoura H, Mosbah H, Santos-Buelga C, González-Paramás AM, Ciudad-Mulero $\mathrm{M}$, et al. Revalorization of wild Asparagus stipularis Forssk. as a traditional vegetable with nutritional and functional properties. Food Funct. 2018;9(3):1578-86. doi: 10.1039/ c7fo01687e.

43. Eddouks M, Lemhadri A, Hebi M, El Hidani A, Zeggwagh NA, El Bouhali B, et al. Capparis spinosa L. aqueous extract evokes antidiabetic effect in streptozotocin-induced diabetic mice. Avicenna J Phytomed. 2017;7(2):191-8.

44. Abdel-Hassan IA, Abdel-Barry JA, Tariq Mohammeda S. The hypoglycaemic and antihyperglycaemic effect of citrullus colocynthis fruit aqueous extract in normal and alloxan diabetic rabbits. J Ethnopharmacol. 2000;71(12):325-30. doi: 10.1016/s0378-8741(99)00215-9.

45. Al-Ghaithi F, El-Ridi MR, Adeghate E, Amiri MH. Biochemical effects of Citrullus colocynthis in normal and diabetic rats. Mol Cell Biochem. 2004;261(1-2):143-9. doi: 10.1023/b:mcbi.0000028749.63101.cc.

46. Ghorbani A, Shafiee-Nick R, Rakhshandeh H, Borji A. Antihyperlipidemic effect of a polyherbal mixture in streptozotocin-induced diabetic rats. J Lipids. 2013;2013:675759. doi: 10.1155/2013/675759.

47. Rathee S, Kamboj A. Optimization and development of antidiabetic phytosomes by the Box-Behnken design. J Liposome Res. 2018;28(2):161-72. doi: 10.1080/08982104.2017.1311913.

48. Ghauri AO, Ahmad S, Rehman T. In vitro and in vivo antidiabetic activity of Citrullus colocynthis pulpy flesh with seeds hydro-ethanolic extract. J Complement Integr Med. 2020;17(2). doi: 10.1515/jcim-2018-0228.

49. Nicola WG, Ibrahim KM, Mikhail TH, Girgis RB, Khadr ME. Role of the hypoglycemic plant extract cleome droserifolia in improving glucose and lipid metabolism and its relation to insulin resistance in fatty liver. Boll Chim Farm. 1996;135(9):507-17.

50. Motaal AA, Ezzat SM, Haddad PS. Determination of bioactive markers in Cleome droserifolia using cell-based bioassays for antidiabetic activity and isolation of two novel active compounds. Phytomedicine. 2011;19(1):3841. doi: 10.1016/j.phymed.2011.07.003.

51. Danciu C, Muntean D, Alexa E, Farcas C, Oprean C, Zupko $\mathrm{I}$, et al. Phytochemical characterization and evaluation of the antimicrobial, antiproliferative and pro-apoptotic potential of Ephedra alata Decne. hydroalcoholic extract against the MCF-7 breast cancer cell line. Molecules. 2018;24(1). doi: 10.3390/molecules24010013.

52. Eddouks M, Lemhadri A, Zeggwagh NA, Michel JB. Potent hypoglycaemic activity of the aqueous extract of Chamaemelum nobile in normal and streptozotocininduced diabetic rats. Diabetes Res Clin Pract. 2005;67(3):189-95. doi: 10.1016/j.diabres.2004.07.015.

53. Shabana MM, Mirhom YW, Genenah AA, Aboutabl EA, Amer HA. Study into wild Egyptian plants of potential medicinal activity. Ninth communication: hypoglycaemic activity of some selected plants in normal fasting and alloxanised rats. Arch Exp Veterinarmed. 1990;44(3):38994.

54. Yalamanchili C, Chittiboyina AG, Haider S, Vasquez Y, Khan S, do Carmo JM, et al. In search for potential antidiabetic compounds from natural sources: docking, synthesis and biological screening of small molecules from Lycium spp. (Goji). Heliyon. 2020;6(1):e02782. doi: 10.1016/j.heliyon.2019.e02782.

55. Ghazanfar K, Ganai BA, Akbar S, Mubashir K, Dar SA, Dar MY, et al. Antidiabetic activity of Artemisia amygdalina Decne in streptozotocin induced diabetic rats. Biomed Res Int. 2014;2014:185676. doi: 10.1155/2014/185676.

56. Maghrani M, Lemhadri A, Zeggwagh NA, El Amraoui M, Haloui M, Jouad $\mathrm{H}$, et al. Effects of an aqueous extract of Triticum repens on lipid metabolism in normal and recent-onset diabetic rats. J Ethnopharmacol. 2004;90(23):331-7. doi: 10.1016/j.jep.2003.10.011.

57. Metwally NS, Mohamed AM, Elsharabasy FS. Chemical constituents of the Egyptian Plant Anabasis articulata (Forssk) Moq and its antidiabetic effects on rats with streptozotocin-induced diabetic hepatopathy. J Appl Pharm Sci. 2012;2(4):54-65.

58. Haidari F, Omidian K, Rafiei H, Zarei M, Mohamad Shahi M. Green tea (Camellia sinensis) supplementation to diabetic rats improves serum and hepatic oxidative stress markers. Iran J Pharm Res. 2013;12(1):109-14.

59. Biro A, Gál F, Hegedủs C, Batta G, Cziáky Z, Peitl B, et al. Isolation of allithiamine from Hungarian red sweet pepper seed (Capsicum annuum L.). Heliyon. 2018;4(12):e00997. doi: 10.1016/j.heliyon.2018.e00997.

60. Mohammed A, Koorbanally N, Islam M. Anti-diabetic effect of Capsicum annuum L. fruit acetone fraction in a type 2 diabetes model of rats. Acta Pol Pharm. 2017;74(6):1767-79.

61. El-Desoky GE, Aboul-Soud MA, Al-Numair KS. Antidiabetic and hypolipidemic effects of Ceylon cinnamon (Cinnamomum verum) in alloxan-diabetic rats. J Med Plants Res. 2012;6(9):1685-91. doi: 10.3329/ bpj.v15i2.12577.

62. Naim M, Amjad FM, Sultana S, Islam SN, Hossain MA, Begum R, et al. Comparative study of antidiabetic activity of hexane-extract of lemon peel (Limon citrus) and glimepiride in alloxan-induced diabetic rats. Bangladesh Pharm J. 2012;15(2):131-4.

63. Oboh G, Olasehinde TA, Ademosun AO. Inhibition of enzymes linked to type-2 diabetes and hypertension by essential oils from peels of orange and lemon. Int J Food Prop. 2017;20(Suppl 1):S586-S94. doi: 10.1080/10942912.2017.1303709.

64. Verengai W, Chagonda L, Chitindingu K, Marume A, TadereraT.Ananti-diabeticpoly-herbalmedicineprepared from extracts of Annona stenophylla, Citrus limon and Zingiber officinales. Int J Pharm Sci Res. 2017;8(3):104855. doi: 10.13040/ijpsr.0975-8232.8(3).1048-55.

65. Nwozo S, Adaramoye O, Ajaiyeoba E. Oral administration of extract from Curcuma longa lowers blood glucose and attenuates alloxan-induced hyperlipidemia in diabetic rabbits. Pak J Nutr. 2009;8(5):625-8. doi: 10.3923/ 
pjn.2009.625.628.

66. Essa R, El Sadek AM, Baset ME, Rawash MA, Sami DG, Badawy MT, et al. Effects of turmeric (Curcuma longa) extract in streptozocin-induced diabetic model. J Food Biochem. 2019;43(9):e12988. doi: 10.1111/jfbc.12988.

67. Kalaycıŏlu Z, Gazioğlu I, Erim FB. Comparison of antioxidant, anticholinesterase, and antidiabetic activities of three curcuminoids isolated from Curcuma longa L. Nat Prod Res. 2017;31(24):2914-7. doi: 10.1080/14786419.2017.1299727.

68. Ranjbar B, Pouraboli I, Mehrabani M, Dabiri S, Javadi A. Effect of the methanolic extract of Daucus carota seeds on the carbohydrate metabolism and morphology of pancreas in type I diabetic male rats. Physiol Pharmacol. 2010;14(1):85-93. [Persian].

69. Ahmad MZ, Ali M, Mir SR. Anti-diabetic activity of Ficus carica L. stem barks and isolation of two new flavonol esters from the plant by using spectroscopical techniques. Asian J Biomed Pharm Sci. 2013;3(18):22-8.

70. Ajmal M, Arshad MU, Saeed F, Ahmed T, Khan AU, Baderul-Ain $\mathrm{H}$, et al. Exploring the nutritional characteristics of different parts of fig in relation to hypoglycemic potential. Pak J Life Soc Sci. 2016;14(2):115-22.

71. Chakroun M, Khemakhem B, Mabrouk HB, El Abed H, Makni M, Bouaziz M, et al. Evaluation of anti-diabetic and anti-tumoral activities of bioactive compounds from Phoenix dactylifera L's leaf: In vitro and in vivo approach. Biomed Pharmacother. 2016;84:415-22. doi: 10.1016/j. biopha.2016.09.062.

72. Díaz-de-Cerio E, Rodríguez-Nogales A, Algieri F, Romero M, Verardo V, Segura-Carretero A, et al. The hypoglycemic effects of guava leaf (Psidium guajava L.) extract are associated with improving endothelial dysfunction in mice with diet-induced obesity. Food Res Int. 2017;96:64-71. doi: 10.1016/j.foodres.2017.03.019.

73. Radhika S, Smila K, Muthezhilan R. Antidiabetic and hypolipidemic activity of Punica granatum linn on alloxan induced rats. World J Med Sci. 2011;6(4):178-82.

74. Bhaskar A, Kumar A. Antihyperglycemic, antioxidant and hypolipidemic effect of Punica granatum L flower extract in streptozotocin induced diabetic rats. Asian Pac J Trop Biomed. 2012;2(3):S1764-S9. doi: 10.1016/s22211691(12)60491-2.

75. Emam MA. Comparative evaluation of antidiabetic activity of Rosmarinus officinalis L. and Chamomile recutita in streptozotocin induced diabetic rats. Agric Biol J N Am. 2012;3(6):247-52. doi: 10.5251/ abjna.2012.3.6.247.252.

76. Aali NS, Singh K, Khan M, Rani S. Protective effect of ethanolic extract of Solanum nigrum on the blood sugar of albino rats. Int J Pharm Sci Res. 2010;1(9):97-9.

77. Kasali FM, Kadima JN, Mpiana PT, Ngbolua KT, Tshibangu DS. Assessment of antidiabetic activity and acute toxicity of leaf extracts from Physalis peruviana L. in guinea-pig. Asian Pac J Trop Biomed. 2013;3(11):8416. doi: 10.1016/s2221-1691(13)60166-5.

78. Esmaeili MA, Yazdanparast R. Hypoglycaemic effect of Teucrium polium: studies with rat pancreatic islets. J Ethnopharmacol. 2004;95(1):27-30. doi: 10.1016/j. jep.2004.06.023.
79. Orhan N, Aslan M, Orhan DD, Ergun F, Yeşilada E. Invivo assessment of antidiabetic and antioxidant activities of grapevine leaves (Vitis vinifera) in diabetic rats. J Ethnopharmacol. 2006;108(2):280-6. doi: 10.1016/j. jep.2006.05.010.

80. Soares de Moura R, da Costa GF, Moreira AS, Queiroz EF, Moreira DD, Garcia-Souza EP, et al. Vitis vinifera L. grape skin extract activates the insulin-signalling cascade and reduces hyperglycaemia in alloxan-induced diabetic mice. J Pharm Pharmacol. 2012;64(2):268-76. doi: 10.1111/j.2042-7158.2011.01395.x.

81. Kantsadi AL, Apostolou A, Theofanous S, Stravodimos GA, Kyriakis E, Gorgogietas VA, et al. Biochemical and biological assessment of the inhibitory potency of extracts from vinification byproducts of Vitis vinifera extracts against glycogen phosphorylase. Food Chem Toxicol. 2014;67:35-43. doi: 10.1016/j.fct.2014.01.055.

82. Rani MP, Padmakumari KP, Sankarikutty B, Cherian OL, Nisha VM, Raghu KG. Inhibitory potential of ginger extracts against enzymes linked to type 2 diabetes, inflammation and induced oxidative stress. Int J Food Sci Nutr. 2011;62(2):106-10. doi: $10.3109 / 09637486.2010 .515565$.

83. Jafri SA, Abass S, Qasim M. Hypoglycemic effect of ginger (Zingiber officinale) in alloxan induced diabetic rats (Rattus norvagicus). Pak Vet J. 2011;31(2):160-2.

84. Rani MP, Krishna MS, Padmakumari KP, Raghu KG, Sundaresan A. Zingiber officinale extract exhibits antidiabetic potential via modulating glucose uptake, protein glycation and inhibiting adipocyte differentiation: an in vitro study. J Sci Food Agric. 2012;92(9):1948-55. doi: $10.1002 /$ jsfa.5567.

85. Ashraf R, Khan RA, Ashraf I. Garlic (Allium sativum) supplementation with standard antidiabetic agent provides better diabetic control in type 2 diabetes patients. Pak J Pharm Sci. 2011;24(4):565-70.

86. Huseini HF, Kianbakht S, Hajiaghaee R, Hashem Dabaghian F. Anti-hyperglycemic and antihypercholesterolemic effects of Aloe vera leaf gel in hyperlipidemic type 2 diabetic patients: a randomized double-blind placebo-controlled clinical trial. Planta Med. 2012;78(4):311-6. doi: 10.1055/s-0031-1280474.

87. Choi HC, Kim SJ, Son KY, Oh BJ, Cho BL. Metabolic effects of aloe vera gel complex in obese prediabetes and early non-treated diabetic patients: randomized controlled trial. Nutrition. 2013;29(9):1110-4. doi: 10.1016/j.nut.2013.02.015.

88. Alinejad-Mofrad S, Foadoddini M, Saadatjoo SA, Shayesteh M. Improvement of glucose and lipid profile status with Aloe vera in pre-diabetic subjects: a randomized controlled-trial. J Diabetes Metab Disord. 2015;14:22. doi: 10.1186/s40200-015-0137-2.

89. Huseini HF, Hasani-Rnjbar S, Nayebi N, Heshmat R, Khaliqi Sigaroodi F, Ahvazi M, et al. Capparis spinosa L. (Caper) fruit extract in treatment of type 2 diabetic patients: a randomized double-blind placebo-controlled clinical trial. Complement Ther Med. 2013;21(5):447-52. doi: $10.1016 /$ j.ctim.2013.07.003.

90. Zare R, Nadjarzadeh A, Zarshenas MM, Shams M, Heydari M. Efficacy of cinnamon in patients with type II diabetes 
mellitus: a randomized controlled clinical trial. Clin Nutr. 2019;38(2):549-56. doi: 10.1016/j.clnu.2018.03.003.

91. Wickenberg J, Ingemansson SL, Hlebowicz J. Effects of Curcuma longa (turmeric) on postprandial plasma glucose and insulin in healthy subjects. Nutr J. 2010;9:43. doi: 10.1186/1475-2891-9-43.

92. Banihani SA, Makahleh SM, El-Akawi Z, Al-Fashtaki RA, Khabour OF, Gharibeh MY, et al. Fresh pomegranate juice ameliorates insulin resistance, enhances $\beta$-cell function, and decreases fasting serum glucose in type 2 diabetic patients. Nutr Res. 2014;34(10):862-7. doi: 10.1016/j. nutres.2014.08.003.

93. Huseini HF, Larijani B, Heshmat R, Fakhrzadeh H, Radjabipour B, Toliat T, et al. The efficacy of Silybum marianum (L.) Gaertn. (silymarin) in the treatment of type II diabetes: a randomized, double-blind, placebo- controlled, clinical trial. Phytother Res. 2006;20(12):10369. doi: $10.1002 /$ ptr. 1988 .

94. Ebrahimpour-Koujan S, Pourghassem Gargari B, Mobasseri M, Valizadeh H, Asghari-Jafarabadi M. Lower glycemic indices and lipid profile among type 2 diabetes mellitus patients who received novel dose of Silybum marianum (L.) Gaertn. (silymarin) extract supplement: a triple-blinded randomized controlled clinical trial. Phytomedicine. 2018;44:39-44. doi: 10.1016/j. phymed.2018.03.050.

95. Mahluji S, Attari VE, Mobasseri M, Payahoo L, Ostadrahimi A, Golzari SE. Effects of ginger (Zingiber officinale) on plasma glucose level, HbAlc and insulin sensitivity in type 2 diabetic patients. Int J Food Sci Nutr. 2013;64(6):682-6. doi: 10.3109/09637486.2013.775223. 